\title{
PENDAMPINGAN PEMBIAYAAN PADA UNIT BISNIS AGROINDUSTRI MINYAK KELAPA DARA DI KABUPATEN LOMBOK UTARA
}

\author{
Tajidan $^{1 *}$, Efendy ${ }^{1)}$, Halil $^{1)}$, FX Edy Fernandez ${ }^{1)}$ \\ Fakultas Pertanian Universitas Mataram \\ ${ }^{*}$ Korespondensi: m_tajidan@unram.ac.id \\ Diterima 25 Maret 2019 / Disetujui 12 Juni 2019
}

\begin{abstract}
ABSTRAK
Tujuan dilaksanakannya pengabdian pada masyarakat ini adalah: mendampingi Anggota Kelompok Barisan Kemitraan PT Telkom dalam mendapatkan pembiayaan dengan biaya modal yang minimal dan pemanfaatannya secara efektif dan efisien. Pencapaian tujuan tersebut dilaksanakan pelatihan dan pendampingan pembiayaan pada anggota kelompok Barisan Kemitraan PT Telkom yang mengusahakan agroindustri minyak kelapa dara. Metode yang diterapkan adalah metode pelatihan dan pendidikan orang dewasa (andragogy). Pelaksanaan kegiatan meliputi pelatihan dan pendampingan pemenuhan persyaratan, pengusulan, penilaian kelayakan, dan pengalokasian pembiayaan. Hasil kegiatan pengabdian adalah: transfer teknologi melalui literasi teknologi dan pendampingan pembiayaan dapat meningkatkan pengetahuan, keterampilan pengolahan minyak kelapa dara, dan terbentuk unit bisnis agroindustri VCO, serta mengalokasikan pembiayaan terdiri atas modal investasi 53,8\% dan modal kerja 46,2\%; alokasi ini dinilai efektif dan efisien yang ditunjukkan oleh perolehan nilai tambah sebesar $\mathrm{Rp} 83.200 /$ liter dengan ratio nilai tambah terhadap nilai output $54,75 \%$, dan ratio nilai tambah terhadap biaya bahan baku 1,85 .
\end{abstract}

Kata Kunci: kredit, literasi, nilai tambah, modal, unit bisnis.

\section{PENDAHULUAN}

Berdasarkan hasil Kajian Forum CSR Daerah Kabupaten Lombok Utara tahun 2018 bahwa potensi pembiayaan yang bersumber dari Program Kemitraan dan Bina Lingkungan (PKBL) Tanggung Jawab Sosial Perusahaan (Corporate Social Responsibility, CSR) cukup besar mencapai empat sampai tujuh milyar rupiah per tahun. Potensi tersebut belum dimanfaatkan secara maksimal disebabkan belum diketahui oleh masyarakat dan sedikitnya usulan dari masyarakat yang disampaikan ke perusahaan-perusahaan (Suparmin, et al., 2018).

Permasalahan sebagai mana disebutkan di atas telah diinisiati oleh Badan Perencanaan Pembangunan Daerah (Bappeda) Kabupaten Lombok Utara untuk membentuk Forum CSR Daerah Kabupaten Lombok Utara, namun karena kendala peraturan perundang-undangan diantaranya belum adanya Peraturan Daerah (Perda) tentang CSR, maka Forum CSR Daerah tersebut belum terbentuk hingga awal tahun 2019 (Tajidan, 2018).

Potensi pembiayaan yang bersumber dari CSR tersebut demikian besar, namun belum dimanfaatkan secara maksimal merupakan permasalahan yang tidak saja dirasakan oleh Pemerintah Daerah selaku pemangku kepentingan masyarakat, dan juga sangat dibutuhkan oleh para pengusaha mikro kecil untuk memenuhi pembiayaannya. Yang menjadi permasalahan adalah para pengusaha mikro kecil belum mengetahui persyaratan dan prosedur mendapatkan bantuan 
tambahan modal yang bersumber dari CSR tersebut, kalaupun sebagian pengusaha mikro kecil telah mengetahui persyaratan dan prosedurnnya, naman bagaimana teknis pengurusannya membutuhkan pendampingan, karena lokasi kantor pusat yang tidak berkedudukan di wilayah Kabupaten Lombok Utara. Efisiensi proses pengurusannya perlu ada perwakilan di wilayah Kabupaten Lombok Utara yang dapat menjembatani antara para pengusaha mikro kecil dengan perusahaan yang memiliki sumber pembiayaan.

Satu di antara perusahaan yang telah merintis penyaluran tambahan modal kepada para pengusaha mikro kecil di Kabupaten Lombok Utara adalah PT Telkom Wilayah Nusa Tenggara Barat yang berkedudukan di Jalan Pendidikan Kota Mataram. Pada kegiatan pengabdian kepada masyarakat pada tahun 2018 telah dilakukan sosialisasi pembiayaan yang bersumber dari PKBL-CSR PT Telkom, (1) kepada para pengusaha tahu di Kecamatan Tanjung dan Kecamatan Gangga yang dilaksanakan di Aula Kantor Desa Gondang, (2) kepada para pendamping lapang wirausaha baru yang dilaksanakan di Tenda Kantor Bappeda Kabupaten Lombok Utara. Sosialisasi PKBL-CSR PT Telkom telah ditindaklanjuti dengan mendata namanama pengusaha mikro kecil yang berminat untuk mendapatkan tambahan modal. Dari peserta yang hadir pada saat sosialisasi menujukkan bahwa sebagian besar peserta berminat untuk mendapatkan tambahan modal untuk memenuhi pembiayaan usaha mereka. Bagi yang berminat diberikan forumulir pendaftaran dan diminta melengkapi persyaratan yang diperlukan (Suparmin, et al., 2018; Sahidu, et at., 2018).

PKBL-CSR PT Telkom telah menyalurkan tambahan modal kepada 17 (tujuh belas orang) pengusaha mikro kecil di Kabupaten Lombok Utara, selanjutnya mereka membentuk kelompok usaha mikro kecil yang diberinama Baskom singkatan dari Barisan Kemitraan PT Telkom yang berkedudukan di Desa Sokong Kecamatan Tanjung - Kabupaten Lombok Utara. Kelompok Baskom yang menjadi penghubung antara PT Telkom dengan para mitranya di Kabupaten Lombok Utara dalam mengajukan permohonan, sementara pencairan tambahan modal dan pengembalian pinjaman tiap bulan dilakukan langsung oleh para mitra dari dan ke PT Telkom dengan transfer rekening (Tajidan, 2018).

Bencana gempa bumi yang terjadi selama bulan Juli dan Agustus 2018 telah mengakibatkan kegiatan ekonomi produktif terhenti, diantanya adalah kegiatan pengolahan hasil-hasil pertanian (agroindustri) minyak kelapa termasuk produksi minyak kelapa dara (virgin coconut oil, V(O). Pengolahan minyak kelapa dara telah dilakukan pelatihan oleh dinas / instansi terkait, diantaranya oleh Dinas Perkebunan Provinsi Nusa Tenggara Barat pada tahun 2013 dan Dinas Pertanian Perkebunan Kehutanan Kelautan dan Perikanan (DKKPP) Kabupaten Lombok Utara pada tahun 2017, serta pelatihan yang dilakukan oleh Lembaga Swadaya Masyarakat. Oleh karena seringnya dilakukan pelatihan oleh berbagai pihak, maka kelompok sasaran telah memiliki pengetahuan dan keterampilan dalam teknis produksi dan pengemasannya.

Permasalahan yang masih mengganjal adalah keterbatasan sumbersumber pembiayaan yang dapat dimanfaatkan untuk meningkatkan kapasitas produksi dan pemasaran (Rahman, 1999). Di antara sumber pembiayaan yang berpeluang untuk dimanfaatkan adalah pembiayaan dari PKBL - CSR PT Telkom dan dari Kredit Usaha Rakyat disalurkan oleh bank-bank pemerintah (Anggraini dan Nasution, 2013), seperti Bank Rakyat Indonesia (BRI), Bank Negara Indonesia (BNI), Bank NTB 
Syariáh dan Bank Mandiri. Untuk meraih sumber pembiayaan tersebut diperlukan adanya pihak yang menghubungkan antara pengusaha agroindustri $V C O$ dengan lembaga keuangan perbankan dan lembaga keuangan non perbankan yang berkedudukan di Kota Mataram dan/atau memiliki cabang di wilayah Kabupaten Lombok Utara, selanjutnya mengefisiensikan alokasi pemanfaatannya untuk pembiayaan operasional dan pembiayaan investasi atau diperlukan pengawalan agar pemanfaatan pembiayaan sesuai dengan rencana penggunaannya.

Kegiatan pengabdian kepada masyarakat bertujuan untuk: mendampingi Anggota Kelompok Barisan Kemitraan PT Telkom dalam mendapatkan pembiayaan dengan biaya modal yang minimal dan pemanfaatannya secara efektif dan efisien.

3. Tahapan Pelaksanaan Kegiatan

Tabel 1. Rincian Kegiatan, Indikator Pencapaian Tujuan dan Tolok Ukur Keberhasilan

\begin{tabular}{|c|c|c|c|}
\hline No & Rincian Kegiatan & $\begin{array}{c}\text { Indikator Pencapaian } \\
\text { Tujuan }\end{array}$ & Tolok Ukur Keberhasilan \\
\hline 1 & Persiapan & & \\
\hline 1.1 & Rapat Persiapan & & \\
\hline \multirow{6}{*}{1.2} & $\begin{array}{l}\text { Pembagian Tugas } \\
\text { Tim Pelaksana }\end{array}$ & $\begin{array}{l}\text { Dicapai kesepakatan } \\
\text { pembagian tugas yang jelas } \\
\text { bagi setiap tim pelaksana }\end{array}$ & $\begin{array}{l}\text { Tersusunnya uraian tugas } \\
\text { tiap-tiap personalia tim } \\
\text { pelaksana }\end{array}$ \\
\hline & $\begin{array}{l}\text { Penyusunan } \\
\text { kebutuhan bahan } \\
\text { dan peralatan }\end{array}$ & $\begin{array}{l}\text { Diperolehnya kuantitas dan } \\
\text { kualitas bahan dan } \\
\text { peralatan yang dibutuhkan }\end{array}$ & $\begin{array}{l}\text { Tersedianya bahan dan } \\
\text { peralatan yang } \\
\text { dibutuhkan }\end{array}$ \\
\hline & $\begin{array}{l}\text { Penyusunan jadwal } \\
\text { tentatif kegiatan }\end{array}$ & $\begin{array}{l}\text { Tersusunnya struktur dan } \\
\text { program pendampingan }\end{array}$ & $\begin{array}{l}\text { Dihasilkannya jadwal } \\
\text { tentatif kegiatan } \\
\text { pendampingan }\end{array}$ \\
\hline & Langkah Persiapan & & \\
\hline & $\begin{array}{l}\text { Observasi kelompok } \\
\text { sasaran }\end{array}$ & $\begin{array}{l}\text { Inventarisasi rencana lokasi } \\
\text { dan kelompok sasaran }\end{array}$ & $\begin{array}{l}\text { Tersususnnya daftar } \\
\text { lokasi dan peserta yang } \\
\text { menjadi kelopok sasaran }\end{array}$ \\
\hline & $\begin{array}{l}\text { Kontrak } \\
\text { Pendampingan }\end{array}$ & $\begin{array}{l}\text { Dicapainya kontribusi } \\
\text { masing-masing pihak dalam } \\
\text { pelaksanaan pendampingan }\end{array}$ & $\begin{array}{l}\text { Dicapinya kesepahaman } \\
\text { antara tim pelaksana dan } \\
\text { kelompok sasaran }\end{array}$ \\
\hline
\end{tabular}

\section{METODE PELAKSANAAN}

1. Waktu dan Tempat Pelaksanaan

Pendampingan pembiayaan dilaksanakan dari bulan Juni sampai dengan bulan Juli 2019 di Unit Bisnis Agroindustri VCO Andana di Dusun Karang Kates Desa Gondang Kecamatan Gangga.

2. Metode Kegiatan

Pelaksanaan

literasi pembiayaan menggunakan metode pelatihan dan pendidikan orang dewasa (andragogy), yaitu suatu metode pembebasan dengan merekonstruksi pengetahuan dan pengalaman pengusaha agroindustri minyak kelapa dara menjadi pengetahuan dan keterampilan yang berstruktur dan bermanfaat dalam mendapatkan sumber pembiayaan dengan biaya yang rendah dan pengalokasian pemanfaatannya secara efektif dan efisien. 


\begin{tabular}{|c|c|c|c|}
\hline No & Rincian Kegiatan & $\begin{array}{c}\text { Indikator Pencapaian } \\
\text { Tujuan }\end{array}$ & Tolok Ukur Keberhasilan \\
\hline & $\begin{array}{l}\text { Negosiasi dan } \\
\text { perjanjian kerjasama } \\
\text { pendampingan }\end{array}$ & $\begin{array}{l}\text { Memperoleh kesepakatan } \\
\text { antara pengurus kelompok } \\
\text { dan ketua tim pelaksana } \\
\text { dan mahasiswa KKN atas } \\
\text { pembagian peran dan } \\
\text { kontribusi pembiayaan dan } \\
\text { dukungan fasilitas } \\
\text { penyelenggaraan } \\
\text { pengabdian }\end{array}$ & $\begin{array}{l}\text { Tercapainya kesepakatan } \\
\text { kontribusi pada kegiatan } \\
\text { pendampingan }\end{array}$ \\
\hline & $\begin{array}{l}\text { Penyiapan peralatan } \\
\text { dan bahan } \\
\text { pendampingan }\end{array}$ & $\begin{array}{l}\text { Memperoleh peralatan dan } \\
\text { bahan-bahan yang } \\
\text { diperlukan dalam kegiatan } \\
\text { pendampingan }\end{array}$ & $\begin{array}{l}\text { Terkumpulnya seluruh } \\
\text { kebutuhan peralatan dan } \\
\text { bahan-bahan } \\
\text { pendampingan }\end{array}$ \\
\hline & $\begin{array}{l}\text { Penyusunan kisi-kisi } \\
\text { instrumen evaluasi }\end{array}$ & $\begin{array}{l}\text { Memperoleh daftar kisi-kisi } \\
\text { instrumen evaluasi awal dan } \\
\text { evaluasi akhir }\end{array}$ & $\begin{array}{l}\text { Terukurnya kapasitas } \\
\text { pengetahuan dan } \\
\text { keterampilan yang } \\
\text { dikuasasi oleh peserta } \\
\text { pendampingan }\end{array}$ \\
\hline & $\begin{array}{l}\text { Penyusunan materi } \\
\text { pendampingan }\end{array}$ & $\begin{array}{l}\text { Mengiventarisasi dan } \\
\text { menyusun materi } \\
\text { pendampingan untuk } \\
\text { mencapai tujuan } \\
\text { pelaksanaan kegiatan } \\
\text { pengabdian }\end{array}$ & $\begin{array}{l}\text { Tersususnnya materi } \\
\text { pendampinghan secara } \\
\text { kronologis sesuai jadwal } \\
\text { pelaksanaan kegiatan }\end{array}$ \\
\hline 1.3 & Evaluasi awal & $\begin{array}{l}\text { Peserta mengikuti evaluasi } \\
\text { awal untuk mendapatkan } \\
\text { gambaran kemampuan } \\
\text { pengetahuan dan } \\
\text { penguasaan keterampilan } \\
\text { persyaratan, prosedur } \\
\text { pengusulan pembiayaan } \\
\text { dan strategi bauran } \\
\text { pemasaran }\end{array}$ & $\begin{array}{l}\text { Memperoleh nilai evaluasi } \\
\text { awal tiap-tiap peserta }\end{array}$ \\
\hline 2 & Pelaksanaan & & \\
\hline 2.1 & Studi Kunjungan & $\begin{array}{l}\text { Meningkatkan keyakinan } \\
\text { peserta bahwa usaha mikro } \\
\text { kecil bersedia dan siap } \\
\text { menjalin kerjasama } \\
\text { kemitraan dengan PT }\end{array}$ & $\begin{array}{l}\text { Meningkatkan minat } \\
\text { kelompok sasaran dalam } \\
\text { mengikuti kegiatan } \\
\text { pelatihan dan } \\
\text { pendampingan }\end{array}$ \\
\hline 2.2 & $\begin{array}{l}\text { Pelaksanaan } \\
\text { pendampingan }\end{array}$ & $\begin{array}{l}\text { Peserta mengikuti seluruh } \\
\text { tahapan pendampingan } \\
\text { secara ajek }\end{array}$ & $\begin{array}{l}\text { Minimal } 100 \% \text { semua } \\
\text { kelompok sasaran } \\
\text { mengkuti seluruh tahapa } \\
\text { pelaksanaan } \\
\text { pendampingan }\end{array}$ \\
\hline
\end{tabular}




\begin{tabular}{|c|c|c|c|}
\hline No & Rincian Kegiatan & $\begin{array}{c}\text { Indikator Pencapaian } \\
\text { Tujuan }\end{array}$ & Tolok Ukur Keberhasilan \\
\hline & Kontrak belajar & $\begin{array}{l}\text { Memperoleh kesepakatan } \\
\text { tentang tata tertib } \\
\text { pendampingan }\end{array}$ & $\begin{array}{l}\text { Peserta disiplin dalam } \\
\text { mengikuti pendampingan }\end{array}$ \\
\hline & Tatap muka indoor & $\begin{array}{l}\text { Peserta mengikuti } \\
\text { pendampingan di ruang } \\
\text { kelas }\end{array}$ & $\begin{array}{l}\text { Peserta mampu mengikuti } \\
\text { kegiatan pendampingan }\end{array}$ \\
\hline & $\begin{array}{l}\text { Praktik strategi } \\
\text { pemasaran bauran }\end{array}$ & $\begin{array}{l}\text { Peserta mengikuti praktik } \\
\text { stragei pemasaan bauran }\end{array}$ & $\begin{array}{l}\text { Peserta terampil dalam } \\
\text { melakukan pategi praktik } \\
\text { strategi bauran }\end{array}$ \\
\hline 2.3 & Pendampingan & $\begin{array}{l}\text { Tim pelaksana aktif } \\
\text { melakukan pendampingan } \\
\text { kepada kelompok sasaran }\end{array}$ & $\begin{array}{l}\text { Peningkatan omzet } \\
\text { penjualan }\end{array}$ \\
\hline 3 & $\begin{array}{l}\text { Monitoring dan } \\
\text { Evaluasi }\end{array}$ & & \\
\hline 3.1 & Monitoring & $\begin{array}{l}\text { Melakukan observasi } \\
\text { pendampingan untuk } \\
\text { mengetahui respon peserta } \\
\text { terhadap materi } \\
\text { pendampingan }\end{array}$ & $\begin{array}{l}\text { Meningkatkan partisipasi } \\
\text { peserta dalam mengikuti } \\
\text { pendampingan }\end{array}$ \\
\hline 3.2 & Evaluasi Pelaksanaan & $\begin{array}{l}\text { Peserta mengikuti evaluasi } \\
\text { akhir }\end{array}$ & $\begin{array}{l}\text { Peningakatan } \\
\text { pengetahuan } \\
\text { keterampilan pengusaha } \\
\text { mikro kecil yang } \\
\text { ditunjukkan oleh } \\
\text { peningkatan nilai arus kas } \\
\text { masuk }\end{array}$ \\
\hline
\end{tabular}

\section{HASIL DAN PEMBAHASAN}

1. Literasi Teknologi Produksi Minyak Kelapa Dara

Proses produksi minyak kelapa dara diperoleh melalui literasi teknologi. Literasi teknologi produksi adalah proses penyerapan pengetahuan melalui telaah literatur di media sosial, direcord atau dicatat, selanjutnya didiskusikan dengan pengurus dan anggota Kelompok Barisan Kemitraan PT Telkom.

Alih keterampilan dilaksanakan dengan menerapkan metode magang (belajar sambil bekerja) pada unit bisnis Agroindustri VCO "Nyiur Daye"di Dusun Karang Raden Desa Sokong
Kecamatan Tanjung. Praktik magang dilaksanakan pada bulan Mei 2019. Proses produksi minyak kelapa dara sebagai berikut:

a. Pembuatan Santan Kelapa

Pembuatan santan diawali dengan pemilihan buah kelapa tua, bernas dan daging buah yang tebal. Buah kelapa dikupas kulitnya dengan menggunakan parang atau linggis sampai diperoleh biji kelapa (Gambar 1). Tempurung kelapa dibersihkan menggunakan parang. Daging buah kelapa dicuci dengan air bersih dan ditiriskan (Gambar 2) dan parut. Proses pemarutan menggunakan mesin, bisa juga 
menggunakan parut konvensional (Gambar 3).

Parutan kelapa dicampur air, diaduk, dan diperas untuk memperoleh santan. Pemeraan santan kelapa dilakukan satu atau dua kali agar memperoleh air santan dengan volume yang optimal.

Santan dipindahkan ke toples transparan dan dibiarkan 2-3 jam sampai terbentuk lapisan air dan lapisan krim (kanil), air tampak di bagian bawah, sementara krim di bagian atas sebagai mana tampak pada Gambar 4.

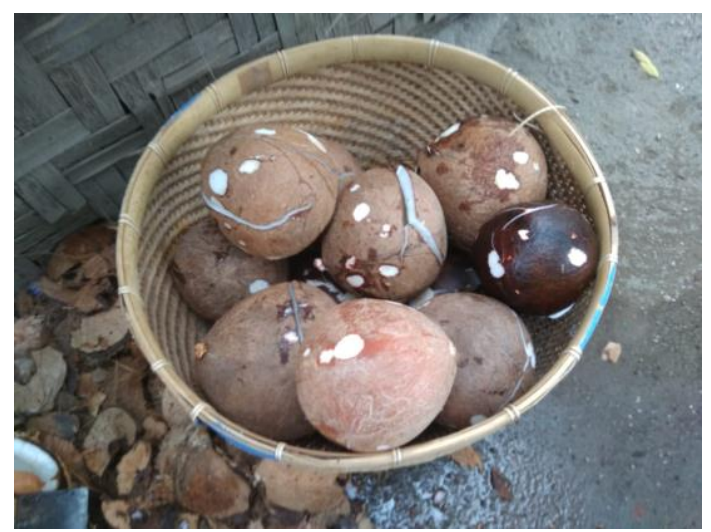

Gambar 1. Daging biji kelapa tua yang sudah dikupas

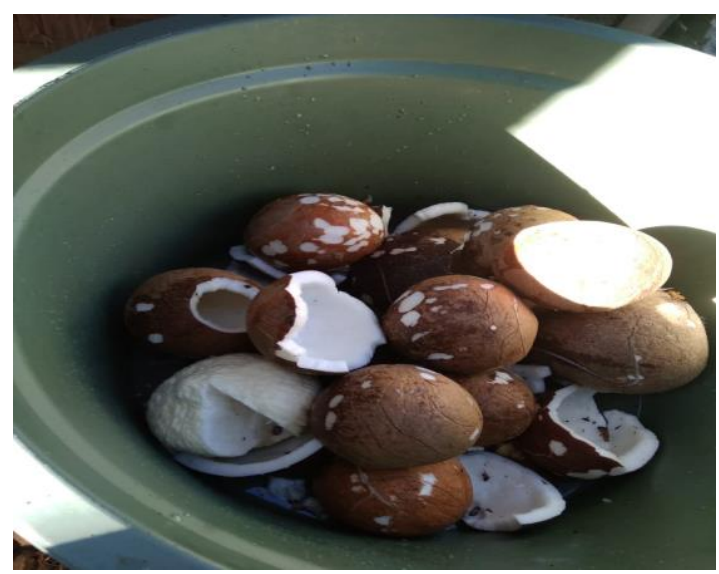

Gambar 2. Daging biji kepala tua yang sudah dicuci dan siap diparut

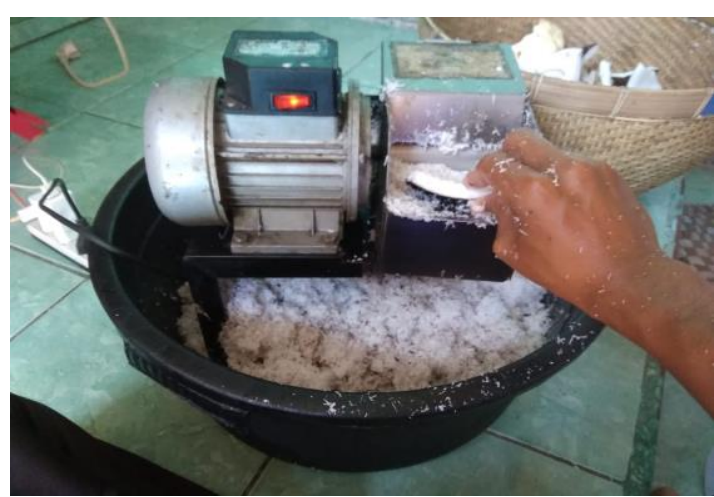

Gambar 3. Proses pemarutan daging biji kelapa

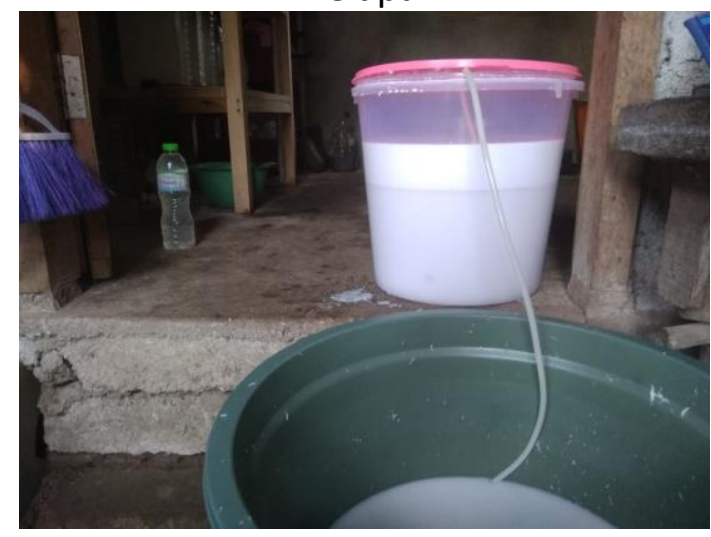

Gambar 4. Proses pemisahan air denan santan

b. Pembuatan VCO

Pembuatan VCO menggunakan metode pemancingan yaitu menggunakan VCO yang sudah jadi sebagai pemancing untuk menghasilkan VCO baru. Krim pada toples transparan ditambahkan VCO dengan perbandingan 3:1, yaitu setiap 3 liter krim ditambahkan 1 liter VCO. Krim dengan VCO diaduk merata. Toples ditutup dan dibiarkan selama 24 jam. Hasilnya akan terbentuk 3 (tiga) lapisan, yaitu VCO di lapisan atas, blondo di lapisan tengah, dan air di lapisan bawah (Gambar 5 dan Gambar 6). 


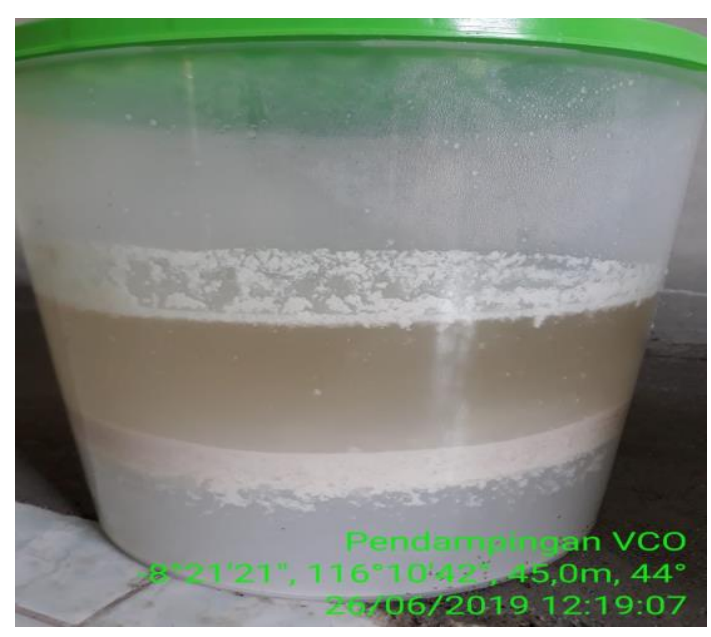

Gambar 5. Pembuatan VCO dengan metode pemancingan

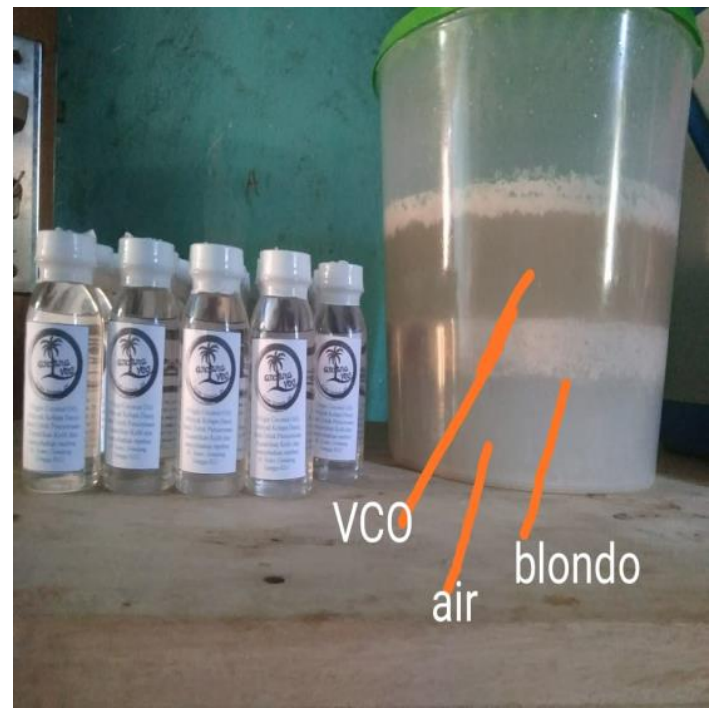

Gambar 6. Pembentukan lapiran VCO, blondo dan air

c. Penyaringan VCO

VCO dan blondo dipisahkan dari air dengan cara mengeluarkan air dari toples. Pemisahan air dari VCO dan blondo menggunakan slang tranparan atau menggunakan toples yang dilengkapi dengan keran pembuangan air (Gambar 7). Proses pemisahan air dari VCO sama dengan proses pemisahan air dari krim, sementara pemisahan VCO dari blondo dilakukan dengan menggunakan kertas saring.

d. Pembotolan dan Pengemasan VCO VCO yang sudah dimurnikan dengan kertas saring dimasukkan ke dalam botol atau rigen, ditutup dan disegel (Gambar 8), selanjutnya diberikan label atau merek yang sudah disiapkan sebelumnya. Botol atau rigen yang sudah diisi VCO dan ditempelkan label, dimasukkan ke dalam kotak. Produk VCO kini siap didistribusikan ke pelanggan.

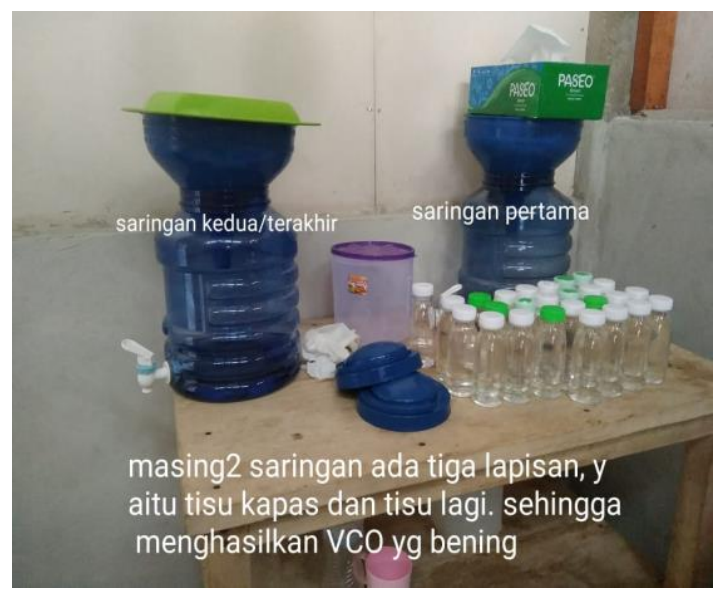

Gambar 7. Penyaringan VCO pertama dan kedua

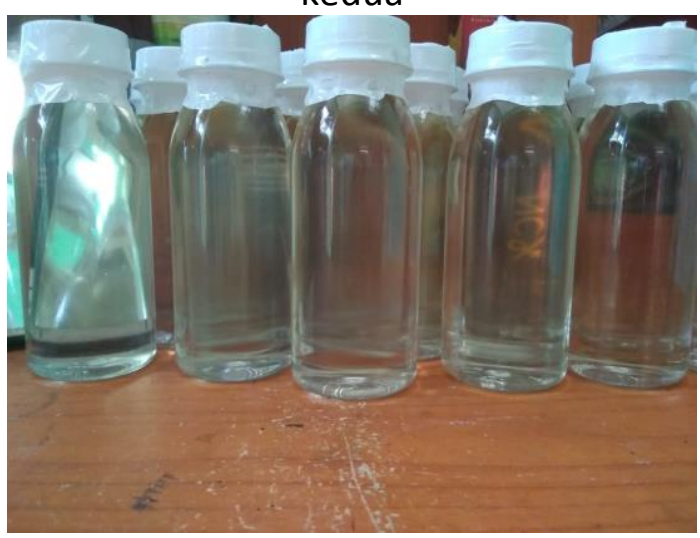

Gambar 8. VCO yang sudah dibotolkan dengan ukuran $100 \mathrm{ml}$

2. Pendampingan

Pencatatan Keuangan

Di antara kelemahan yang umum dijumpai pada unit bisnis skala rumah tangga adalah bercampurnya antara keuangan pribadi dengan keuangan unit bisnis. Keuangan rumah tangga bercampur dengan keuangan bisnis, akibatnya terjadi kerancuan antara biaya produksi dengan pengeluaran rumah tangga. Sebagai langkah awal, maka dilakukan 
pendampingan pencatatan keuangan, yaitu menyisihkan tabungan sebagai modal awal unit bisnis. Modal awal sebesar Rp1.000.000,- dialokasikan untuk memenuhi kebutuhan peralatan atau investasi dan sebagiannya digunakan untuk memenuhi kebutuhan bahan baku dan bahan penolong atau bahan habis pakai lainnya.

3. Pendampingan

Sumber Pembiayaan

a. Kredit Usaha Rakyat (KUR)

Sumber pembiayaan bagi usaha kecil menengah adalah KUR. KUR merupakan kredit program yang disalurkan melalui bank pemerintah, yaitu BRI, BNI, Bank Mandiri, dan Bank Milik Pemerintah Daerah. Persyaratan mendapatkan KUR adalah: Individu atau perseorangan yang memiliki usaha ekonomi produktif; Perseorangan yang telah menjalankan usaha aktif minimal 6 (enam) bulan; Tidak dalam proses mendapatkan kredit dari bank manapun atau dari koperasi, kecuali kredit konsumtif seperti KPR, Kartu Kredit dan KKB. Persyaratan administrasi : KTP, KK, Surat Keterangan Usaha/Ijin Usaha, Pasfoto, materai Rp 6000 sebanyak 2 (dua) lembar; Memiliki Nomor Rekening Bank yang bersangkutan.

Pinjaman maksimal Rp25.000.000 (dua puluh lima juta) bebas agunan dengan masa pengembalian 3 (tiga) tahun untuk modal kerja, dan 4 (empat) tahun untuk modal investasi. Bunga 7\%/tahun flat.

Prosedur mengajuan KUR adalah perseorangan datang ke bank membawa persyaratan dan mengisi formulir. Formulir dan semua persyaratan diserahkan ke bagian kredit, setelah diterima menunggu beberapa minggu untuk dilakukan pemeriksaan dan BI Checking. Apabila persyaratan telah lengap dilakukan survey ke lokasi usaha untuk dinilai kelayakannya. Jika telah memenuhi semua persyaratan, maka pengusul dipanggil untuk menandatangani kontrak, selanjutnya kredit ditrasnfer ke rekening nasabah.

Pengembalian pinjaman dilakukan dengan datang langsung ke bank atau ditransfer ke rerekening pengembalian, atau dilakukan autodebet oleh bank.

b. Program Kemitraan dan Bina Lingkungan (PKBL)

Kredit PKBL adalah kredit yang disalurkan oleh Badan Usaha Miliki Negara (BUMN) kepada pengusaha kecil menengah, contohnya PKBL CSR yang disalurkan oleh PT Telkom Wiayah Nusa Tenggara Barat. Persyaratan mendapatkan kredit PKBL CSR adalah: pengusahanya telah berpengalamanan minimal 6 bulan (usaha pemula); mengisi formulir; memperoleh rekomendasi/ persetujuan dari instansi / dinas teknis; membuka rekening; memiliki KTP dan KK; memiliki Surat Keterangan Usaha dari Kantor Desa. Ketentuan PKBL-CSR adalah: pinjaman antara Rp 5 juta - Rp 20 juta tanpa agunan; bunga $3 \% /$ tahun; jangka waktu 
pinjaman maksimal 24 bulan dengan masa tenggang satu buan; angsuran dilakukan tiap bulan atau per musim panen, sesuai kondisi UMKM. Realisasi dan pengembalian pinjaman dilakukan melalui transfer rekening.

4. Pendampingan Pemanfaatan Pembiayaan

Unit bisnis "Andana" VCO baru memulai usaha pada bulan Juni 2019, sehingga belum memenuhi persyaratan untuk mengusulkan pembiayaan yang bersumber dari KUR maupun PKBL-
CSR PT Telkom. Oleh karena itu diharapkan melengkapi semua persyaratan yang diperlukan, termasuk penyiapan dokumen administrasi yang dibutuhkan.

Sebagai

proses penyadaran dan penumbuhan usaha, maka dimulai dengan menggunakan modal sendiri atau modal yang bersumber dari diri pribadi yang disisihkan untuk memulai (start up) usaha dengan modal awal Rp1.000.000,- Modal awal ini dimanfaatkan untuk memenuhi modal investasi dan modal kerja.

Tabel 2. Alokasi Pemanfaatan Pembiayaan Unit Bisnis "Andana"VCO

\begin{tabular}{|c|c|c|c|c|c|}
\hline No & Uraian & Volume & satuan & $\begin{array}{c}\text { Harga } \\
\text { (Rp/unit) }\end{array}$ & Nilai (Rp) \\
\hline \multicolumn{6}{|c|}{ 1. Modal Investasi } \\
\hline a. & Mesin parut & 1 & Unit & 250.000 & 250.000 \\
\hline b. & Bak karet besar & 1 & Unit & 55.000 & 55.000 \\
\hline c. & Bak karet sedang & 2 & Unit & 35.000 & 70.000 \\
\hline d. & Toples & 2 & Unit & 31.500 & 63.000 \\
\hline e. & Corong & 2 & Unit & 10.000 & 20.000 \\
\hline f. & Rigen & 2 & Unit & 15.000 & 30.000 \\
\hline g. & Bibit VCO & 1 & Liter & 50.000 & 50.000 \\
\hline & $\begin{array}{l}\text { Jumlah Modal } \\
\text { Investasi }\end{array}$ & & $\mathrm{Rp}$ & & 538.000 \\
\hline
\end{tabular}

\begin{tabular}{lllr}
\hline 2. Modal Kerja & & & \\
a. Kas & & Rp & 74.000 \\
b. Botol & 100 & Unit & 200.000 \\
c. Tissue & 2 & kotak & 24.000 \\
d. Penyaring & 7 & Unit & 14.000 \\
e. Kelapa & 50 & butir & 2.000 \\
\hline & Jumlah Modal Kerja & Rp & 150.000 \\
\hline & Jumlah Modal & Rp & 462.000 \\
\hline
\end{tabular}

Alokasi pemanfaatan modal tampak sebagai mana Tabel 2 yaitu $53,80 \%$ untuk modal investasi dan $46,20 \%$ untuk modal kerja. Modal investasi merupakan barang modal yang dipakai beberapa kali proses produksi seperti mesin, peralatan, dan bibit VCO. Modal kerja terdiri atas kas, bahan baku, bahan penolong dan bahan-bahan lain yang habis terpakai dalam satu kali proses produksi.

5. Pelatihan dan Pendidikan Literasi Pembiayaan

Pelatihan dan pendidikan literasi pembiayaan dilaksanakan 
pada hari Sabtu, tanggal 27 Juli 2019 di Aula Kantor Desa Sokong Kecamatan Tanjung Kabupaten Lombok Utara. Dalam literasi pembiayaan ini yang bertindak sebagai nara sumber adalah: Pertama: Dr.Ir.FX Edy Fernandez, MP dengan pokok materi "Sumber Pembiayaan Kredit Usaha Rakyat" (Gambar 9). Kedua adalah Raden Sukawati, Ketua Barisan Kemitraan PT Telkom dengan pokok materi "Sosiaisasi CSR PT Telkom" (Gambar 10).

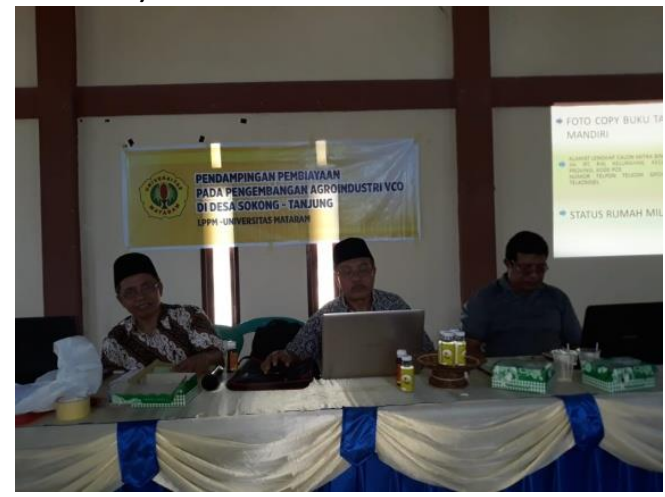

Gambar 9. Penyajian materi tentang sumber pembiayaan $\mathrm{KU}$

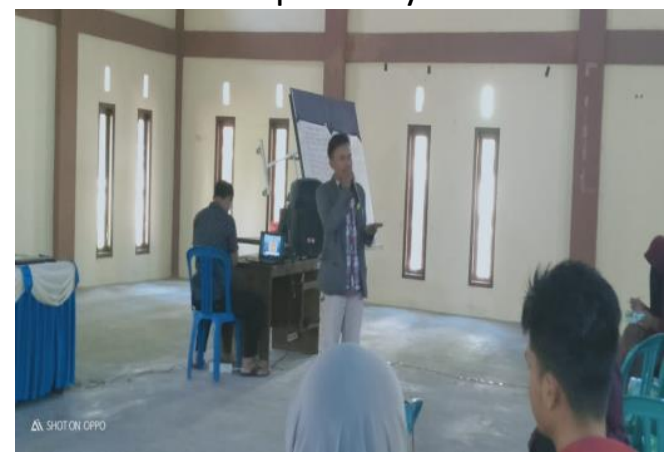

Gambar 10. Penyajian materi tentang sumber pembiayaan PKBL CSR PT Telkom
6. Evaluasi Pre Test dan Post Test

Evaluasi dilakukan pada awal dan akhir literasi pembiayaan. Berdasarkan hasil pre test diketahui bahwa peserta telah memiliki pengetahuan yang cukup tentang materi yang disajikan sebagai dampak dari telah dilakukan pendampingan sejak bulan Juni 2019 sampai dengan akhir Juli 2019. Hasil pre test menujukkan bahwa rata-rata nilai yang diperoleh adalah 77,69. Pada akhir pelaksanaan literasi pembiayaan dilakukan post test dengan perolehan nilai 81,72; artinya ada peningkatan dari hampir unggul menjadi unggul.

7. Manfaat Ekonomi Pendampingan Pembiayaan

Pengukuran manfaat ekonomi literasi dan pendampingan pembiayaan menggunakan metode analisis nilai tambah. Nilai tambah adalah tambahan nilai ekonomi atas pengorbanan bahan baku dan bahan penolong.

$$
N T_{(R p / l t r)}=P_{\text {vco }}(\mathrm{Rp} / \mathrm{ltr})-[\text { Biaya }
$$

Bahan Baku (Rp/liter) + Biaya Bahan

NT = nilai tambah

$$
\text { lainnya }(\mathrm{Rp} / \mathrm{trr})]
$$

$\mathrm{P}=$ Penjualan

Besar nilai tambah pada unit bisnis "Andana" VCO pada bulan Juni 2019 ditampilkan pada Tabel 3.

Tabel 3. Nilai Tambah Pengolahan Kelapa menjadi VCO

\begin{tabular}{llrrrr}
\hline No & \multicolumn{1}{c}{ Uraian } & Volume & Satuan & $\begin{array}{c}\text { Harga } \\
\text { (Rp/unit) }\end{array}$ & Nilai (Rp/liter \\
\hline 1 & Penjualan & 1,0 & Liter & 152.000 & 152.000 \\
2 & Biaya bahan baku & 15,0 & butir & 3.000 & 45.000 \\
3 & Biaya bahan lain & & & & \\
& - Kapas & 0,7 & sheet & 2.000 & 1.400 \\
& • Tisue & 0,2 & kotak & 12.000 & 2.400 \\
& • $\quad$ Botol & 10,0 & unit & 2.000 & 20.000 \\
\hline
\end{tabular}




\begin{tabular}{|c|c|c|c|}
\hline & Jumlah $(2+3)$ & & 68.800 \\
\hline 4 & Nilai Tambah & 1 & 83.200 \\
\hline
\end{tabular}

Nilai tambah proses produksi VCO diperoleh dari hasil analisis mengguakan metode penjualan dan biaya. Nilai tambah hasil dari Penjualan dikurangi Total Biaya Bahan Baku dan Bahan lainnya. Nilai tambah VCO adalah Rp83.200/liter. Ratio nilai tambah terhadap nilai output $54,74 \%$, sementara ratio nilai tambah terhadap biaya bahan baku sebesar 1,85 , artinya setiap rupiah yang dikorbankan untuk bahan baku menghasilkan nilai tambah sebesar 1,85 rupiah.

Hasil penelitian yang dilakukan oleh Setyawan dan Purwanti (2016) di Kabupaten Natuna bahwa nila tambah yang diperoleh dari pengolahan kelapa menjadi VCO sebesar Rp952/liter lebih rendah bila dibandingkan dengan nilai tambah yang diperoleh dari hasil pengolahan yang dihasilkan oleh unit bisnis "Andana"VCO di Kabupaten Lombok Utara.

Hasil penelitian Nabiu, et al. (2006) cit Peirera (2019) bahwa pengolahan kelapa menjadi VCO menguntungkan dengan nilai tambah berkisar antara Rp2.052/butir sampai dengan Rp2.576/butir lebih rendah daripada nilai tambah yang diperoleh pada unit bisnis "Andana" VCO bahwa satu liter VCO membutuhkan 15 butir kelapa, maka nilai tambah yang diperoleh adalah Rp5.547/butir.

Dari tanggal 1 Juni sampai dengan tanggal 30 Juni 2019 dihasilkan 10 liter VCO, maka nilai tambah yang diperoleh selama 1 (satu) bulan adalah
Rp832.000/bulan. Sementara hasil penelitian yang dilakukan oleh Dindy Daryanti Putri (2006) menyatakan nilai tambah yang diperoleh para pengrajin VCO lebih kecil daripada nilai tambah yang diperoleh perusahaan, dan belum mampu memberikan keuntungan bagi pengrajin. Nilai tambah yang diperoleh merupakan penghasilan yang diterima oleh tenaga kerja dalam keluarga dan luar keluarga, artinya ada tambahan penghasilan bagi tenaga. Tambahan yang diperoleh tenaga kerja yang bekerja pada unit bisnis "Andana" VCO adalah Rp832.000/bulan.

\section{KESIMPULAN DAN SARAN}

\section{Kesimpulan}

Transfer teknologi melalui literasi teknologi dan pendampingan pembiayaan dapat meningkatkan pengetahuan, keterampilan pengolahan minyak kelapa dara, dan terbentuk unit bisnis agroindustri VCO, serta mengalokasikan pembiayaan terdiri atas modal investasi $53,8 \%$ dan modal kerja 46,2\%. Alokasi ini dinilai efektif dan efisien yang ditunjukkan oleh perolehan nilai tambah sebesar Rp 83.200/liter dengan ratio nilai tambah terhadap nilai output $54,75 \%$, dan ratio nilai tambah terhadap biaya bahan baku 1,85.

\section{Saran}

Kepada unit bisnis agroindustri “Andana"VCO diharapkan melengkapi semua persyaratan pengusulan pembiayaan yang bersumber dari Kredit Usaha Rakyat atau PKBL-CSR, dan persyaratan memperoleh sertifikat IPRT dari Danas Kesehatan dan sertifikat 
hahal dari Majelis Ulama Indonesia (MUI). Kepada pengusaha unit bisnis agroindustri VCO "Nyiur Daye" agar terus melanjutkan kemitraan dengan pengusaha VCO pemula di wilayah Kabupaten Lombok Utara.

\section{UCAPAN TERIMA KASIH}

Terima kasih disampaikan kepada Ketua Barisan Kemitraan PT Telkom atas kesediaanya bekerjasama dalam pengembangan agroindustri VCO di Kabuaten Lombok Utara, dan terima kasih pula kepada semua pihak yang telah menfasilitasi sehingga kegiatan pengabdian dapat terlaksana.

\section{DAFTAR PUSTAKA}

Anggraini dan Nasution, 2013. Peranan Kredit Usaha Rakyat (KUR) Bagi Pengembangan UMKM di Kota Medan:Kasus Bank BRI. Jurnal Ekonomi dan Keuangan Vol. 1, No. 3, Februari 2013.

Dindy Darmayanti Putri, 2006. Analisis Nilai Tambah VCO Perajin Plasma dan Inti PT Patria Wiyata Vico. Yogyakarta.

Etd.repository.ugm.id.

Nabiu, M., E.Yuliarti, dan E.Manurung, 2006. Analisis Nilai Tambah dan Kemampulabaan Tiga Industri VCO di Kota Bengkulu. https://ejournal.unit.ac.id.

Pereira, M.M., 2019. Analisis Nilai Tambah Virgin Coconut Oil Di Kabupaten Nias Selatan Sumatera Utara. Fakultas Pertanian Univeritas Udaya. Denpasar.

Purnamasari, Dewi K., Syamsuhaidi, Erwan, dan K.G. Wiryawan, 2018. Pendampingan Pemulihan Kondisi Peternakan Ayam Ras Petelur Pasca Gempa di Kabupaten Lombok Utara. Fakultas Peternakan Universitas
Mataram, JI. Majapahit No. 62 Mataram, 83125. http://eprints. unram.ac.id/11234/2/ARTIKEL\% 20DWI\% 20KUSU-MA.pdf

Rahman, A., 1999. Micro-credit initiatives for equitable and sustainable development: Who pays? World Development Volume 27, Issue 1, January 1999, Pages 67-82

Setyawan,S dan E.Purwanti, 2016. Nilai Tambah dan Profitabilitas Komoditas Kelapa di Kabupaten Natuna.www.researtchgate.net diunduh tanggal 30 Juli 2019.

Suparmin, Hirsanuddin, M, Yusuf dan Sri Maryanti, 2018. Kajian Forum CSR Daerah Kabupaten Lombok Utara. Fakultas Pertanian Universitas Mataram dan Bappeda Kabupaten Lombok Utara.

Tajidan, 2018. Laporan Akhir Konsultan Pendamping Pelaksanaan Kegiatan Penyusunan Perencanaan Pengembangan Ekonomi Masyarakat Kabupaten Lombok Utara. Kerjasama Universitas Mataram dengan Bappeda Kabupaten Lombok Utara. 